\title{
Literatura jako element całości kulturowej
}

Danuta Dąbrowska 
Tych kilka uwag wystarczy chyba do potwierdzenia zdania, że wydanie Wierszy politycznych Sejmu Czteroletniego było potrzebne i że — poza wszystkimi innymi funkcjami — stanowi dla badaczy poezji okolicznościowej osiemnastego wieku ważny punkt odniesienia.

Autorka opracowania rzetelnie wykorzystała pozostawiony przez Rabowicza materiał, chociaż bardziej wymagający czytelnik chciałby na pewno dostać znacznie bardziej rozwinięty i pogłębiony - o na przykład omówienie wątków tematycznych i przemian gatunkowych - wstęp. I chciałby także — tu mam nadzieję, że część druga edycji spełni te oczekiwania dysponować alfabetycznym spisem utworów, indeksem incipitów oraz indeksem nazwisk.

Wojciech Kaliszewski

\section{Literatura jako element całości kulturowej}

Nawet pobieżne spojrzenie na najnowszą książkę Janusza Maciejewskiego' ${ }^{1}$. pozwala dostrzec wielość i różnorodność problemów podejmowanych przez autora. Tom Obszary $i$ konteksty literatury jest przy tym bardzo dla dorobku badacza reprezentatywny. Zebrane w nim bowiem zostały prace stanowiące plon wielu lat naukowych dociekań, dotychczas rozproszone w czasopismach i wydawnictwach zbiorowych. Niektóre z nich, okrojone niegdyś przez cenzurę, dopiero teraz ukazują się w pełnym kształcie. Zebrane razem tworzą jakościowo nową całość, dopełniając się i komentując wzajemnie, przede wszystkim zaś ujawniając wagę problemów dla współczesnego literaturoznawstwa niezwykle istotnych, choć często niedocenionych czy spychanych na margines zainteresowań badaczy.

Gdyby chcieć najogólniej określić preferencje naukowe Janusza Maciejewskiego, można by powiedzieć, iż zawierają się one w obrębie socjologii literatury. Stwierdzenie takie wyjaśnia jednak niewiele. Samo bowiem pojęcie socjologii literatury jako kategoria czy metodologia badawcza wywoływało i wywoluje nadal wiele sporów i dyskusji dotyczących zakresu objętych nim zjawisk i możliwości ich badania. Obok mnożących się postulatów włączania do zakresu badań coraz szerszych obszarów odnoszących się do rzeczywistości pozaliterackiej powstają obawy, iż jest to dziedzina kojarząca się z uproszczeniami i wulgaryzacją potocznie rozumianego marksizmu, od którego większość literaturoznawców stanowczo się obecnie odcina. Nie miejsce tu na szczegółową prezentację owych sporów, i jeśli je sygnalizuję, to po to, aby tym wyraźniej ujawniła się zarówno ranga dokonań Maciejewskiego, jak i zawarte w prezentowanej książce inspiracje, pytania, problemy otwierające drogę do dalszych badań.

Nie podejmując sporów metodologicznych i dyskusji nad tym, jakie są zadania i zakres socjologii literatury, autor poprzestaje na ogólnym stwierdzeniu określającym krąg podejmowanych przez siebie zagadnień. Pisze we wstępie do swojej książki: „Socjologią literatury

'J. Maciejewski, Obszary i konteksty literatury, Warszawa 1998, s. 236. 
skłonny jestem nazywać ten typ zainteresowań badawczych, który jest skierowany na to wszystko, co znajduje się poza tekstem literackim, choć jest z tym ostatnim różnymi relacjami związane. (...) Należy do niej cała sfera życia literackiego i szerzej kulturowego (jako że pierwsza jest przecież częścią drugiego). Należą różnego typu zachowania i zjawiska literaturopodobne, czy nie w pełni literackie — choć zawsze towarzyszące właściwej literaturze — jak i te, które mieszczą się na jej "trzecich» obszarach. Rozpatrywanie tych zjawisk jest bowiem ważne ze względu na ich funkcjonowanie społeczne, nie zaś walory artystyczne" (s. 8). Książka prezentuje konkretne zagadnienia związane $z$ funkcjonowaniem literatury w danej sytuacji i rzeczywistości społecznej i historycznej. Pokazuje przy tym, jak ważne dla rozumienia zjawisk literackich są przywołane tu konteksty. Maciejewskiego interesuje tyleż literatura wielka i uznana, co wszelkiego typu teksty użytkowe, okolicznościowe, bytujące na pograniczach kultury oficjalnej, mało znane zjawiska literackie. Przekonywająco udowadnia, iż właśnie tego typu fakty kulturowe mają często ogromne konsekwencje dla kształtowania się świadomości spolecznej i dokonujących się w niej przemian, że często zbiorowość w nich właśnie ujawnia swą tożsamość wyraziściej nawet niż w oficjalnej, uznanej literaturze zaliczanej do narodowego kanonu.

Książka Maciejewskiego podzielona została na pięć, różnych objętościowo, części, z których każda skupia się na odrębnych, acz wchodzących ze sobą w rozliczne związki, zagadnieniach. Trudno byłoby je tu wszystkie równie szeroko omawiać, warto jednak przynajmniej zasygnalizować. Tom otwiera rozprawa dotycząca kategorii pokolenia w badaniach literackich. Pisana jeszcze przed publikacją fundamentalnego dzieła Kazimierza Wyki, uwzględnia jednak jego wcześniejsze prace na ten temat, stanowiąc ich istotne dopełnienie i poszerzenie kręgu problemów dostrzeganych przez Wykę. Część druga zawiera studia poświęcone, jak to autor określa, „obszarom trzecim” literatury, a więc tekstom sytuującym się między literaturą wysoką a folklorem. Maciejewski tworzy tu precyzyjną klasyfikację różnych obszarów literatury, wskazując zarówno na odrębności poszczególnych sfer, jak i miejsca pograniczne czy wspólne, sugerujące przynależność określonych grup tekstów do kilku obszarów, ich wzajemne przenikanie się. Punktem wyjścia dokonywanej klasyfikacji stają się nie wartości estetyczne, lecz przede wszystkim funkcja społeczna utworów. „Funkcja - pisze Maciejewski - w pewnym sensie modeluje tekst. Ten sam utwór może występować w różnych płaszczyznach klasyfikacji. Może być wyrazem folkloru środowiskowego, gdy spontanicznie powstaje i egzystuje w bezpośrednich kontaktach odbiorców bez pośrednictwa oficjalnych środków przekazu. Może stać się exemplum literatury użytkowej, gdy zostanie wydany jako brukowy druczek, liczący na odpustowego czy jarmarcznego czytelnika. Może wreszcie jako taki zostać uznany za trywialny i nastawiony na czytelników trzeciego bądź czwartego obiegu i włączony w klasyfikację przeciwstawiającą sobie literaturę wysoką i niską" (s. 59).

W obrębie przyjętej klasyfikacji autor wyróżnia i charakteryzuje takie formy, jak literatura użytkowa i okolicznościowa, folklor środowiskowy, poezja polityczna, formy dziennikarskie. $\mathrm{Z}$ tych ostatnich szerzej analizuje felieton, śledząc krystalizowanie się gatunku i jego szczy- 
towe osiagnięcie XIX-wieczne, jakim była felietonistyka Bolesława Prusa. W omawianej tu części znalazły się także znakomite, szeroko znane wcześniej, artykuły poświęcone poezji politycznej lat 1763-1788 oraz folklorowi szlacheckiemu wieku XVII i XVIII. Przypominają one, iż Janusz Maciejewski jest uznanym badaczem tego okresu historii literatury, autorem prekursorskich prac poświęconych poezji barskiej i edytorem tekstów okolicznościowych. Studium poświęcone folklorowi szlacheckiemu doskonale pokazuje przy tym, jak złudne może być pisanie historii literatury w oparciu wyłącznie o funkcjonujące oficjalnie utwory wielkiej literatury, z pominięciem ogromnej sfery tego, co nieoficjalne, okazjonalne, zabawowe, ale przecież w omawianym okresie niezwykle reprezentatywne i zaświadczające o rzeczywistym stanie szlacheckiej, potocznej mentalności, jakże często odmiennej od myślenia elit.

W części trzeciej prezentowanego tomu zajął się autor problematyką szeroko rozumianego życia literackiego. Znajdują się tu artykuły poświęcone giełdzie literackiej (a więc tworzeniu się mechanizmów ocen i hierarchii ważności tekstów literackich), krytyce, czytelnikom, relacjom zachodzącym między literaturą, społeczeństwem i władzą. Osobny rozdział poświęcony został sytuacji pisarza i jego twórczości w funkcjonującym po 1989 roku systemie demokratycznym. Stanowi on ważki głos w dyskusji dotyczącej perspektyw polskiej literatury uwolnionej od potrzeby „służby”, ale postawionej wobec zupełnie nowych wymagań czytelników. Autor podejmuje tu także żywo obecnie dyskutowane problemy kultury masowej, jej zagrożeń wobec literatury wysokiej, często stawiającej pisarza w sytuacji koniecznego wyboru: popularność czy zachowanie wysokiej rangi artystycznej. Ujmując powyższą problematykę w porządku historycznym, Maciejewski zwraca także uwagę na te aspekty relacji literatura - demokracja, które obecnie rzadziej pojawiają się w pracach na ten temat. Ukazuje istotne związki pisarzy $z$ własną zbiorowością, ich działania na rzecz demokracji, tworzenie idei asymilowanych przez społeczeństwo. Podobnie jak w innych swoich artykułach, tak i tutaj autor bardzo mocno podkreśla konieczność mówienia nie tylko o literaturze jako wartości autonomicznej, ale także o jej odbiorcach, którzy dokonując wyborów lekturowych poddają się lub nie poddaja presji czy sugestiom pisarza, mogą mieć zupełnie inne od założonych przez niego preferencje, prezentować inne systemy wartości, inaczej widzieć cele literatury itp. Z tymi wszystkimi czynnikami pisarze muszą się liczyć, chcąc istnieć w społecznej świadomości. Analizując zatem związki literatury i demokracji, dostrzega autor te właśnie uwarunkowania, pisząc: „Związek ten nie był zresztą ze strony artystów całkiem bezinteresowny. Popierając bowiem demokrację, liczyli oni, że przyczyni się ona do podniesienia oświaty wśród mas, a zatem i do upowszechnienia kultury. Że więc rozszerzy grono odbiorców sztuki i literatury wysokiej, że wyrwie owe masy z objęć kultury masowej i im właśnie odda we władanie" (s. 137). Rzeczywistość nie potwierdziła jak dotąd zrealizowania się tych dążen, ale to przecież nie przesądza jeszcze o odwróceniu się literatury od demokracji, raczej stawia przed twórcami nowe wyzwania.

Inne studia zawarte w omawianej części poświęcone są głównie analizie instytucji i form życia literackiego, zarówno współczesnych, jak i dawniejszych. Wiele miejsca zajmuje tu 
kategoria mecenatu kulturalnego i jej przemiany uzależnione od zmieniającej się sytuacji społecznej i historycznej, ale także od zmian zachodzących w świadomości samych twórców, ich pojmowania roli pisarza, granic wolności twórczej i gotowości do przyjęcia kompromisów. Na uwagę zasługują również artykuły podejmujące problematykę takich form życia literackiego, jak salon i kawiarnia literacka. Ich specyficzną cechąjest możliwość bezpośredniego kontaktu autorów i odbiorców, których aktywność w procesie wzajemnej komunikacji autor szczególnie uwydatnia. Jakkolwiek w obu przypadkach — salonu i kawiarni - mamy do czynienia z wąską, w pewnym sensie elitarną grupą publiczności czytającej, to jednak stanowi ona ważny czynnik opiniotwórczy, silnie oddziałujący na tworzenie się obiegowych ocen i hierarchii wartości anektowany ch przez ogół, a na pewno przez duże grupy odbiorców. Salon i kawiarnia literacka są przecic $<$ także miejscami, gdzie tworzą się mody i snobizmy literackie, ustala się kanon tekstów, które po prostu wypada znać, choć trzeba odnotować także możliwość negatywnego oddziaływania. Opinia wymienionych kręgów może również skazywać pisarza czy jego poszczególne dzieła na czytelniczy bojkot, i nie zawsze podyktowane jest to wyłącznie ocenami estetycznymi.

Kolejnym tematem podjętym przez Maciejewskiego w czwartej części tomu jest terytorialny, "geograficzny" aspekt piśmiennictwa. Znalazły się tu artykuły dotyczące specyfiki kulturowej pogranicza, funkcjonowania literatury polskiej na różnych obszarach dawnej Rzeczypospolitej w drugiej połowie wieku XIX, a także studia poświęcone twórczości emigracyjnej i różnym aspektom emigracji. Cennym wkładem w badania nad kulturą sarmacką jest artykuł mówiący o wielojęzyczności tej kultury występującej na pograniczu polsko-ukraińsko-białoruskim, pokazujący jednocześnie proces krystalizowania się języka ogólnonarodowego połączony z budowaniem tożsamości narodowej. Doskonale ten proces dostrzec można śledząc przemiany zachodzące w hierarchii ważności poszczególnych języków jako składników czy elementów tekstu literackiego. Umieszczając zjawiska kulturowe w szeroko przywoływanym kontekście wydarzeń historycznych, pokazuje autor dynamikę i wewnętrzną dramaturgię opisywanych procesów, w których kultura staje się często elementem walki politycznej, terenem obrony przed wynarodowieniem czy też, jak miało to miejsce później, w okresie oświecenia, wręcz narzędziem służącym obronie zagrożonej państwowości.

Warte szczególnego odnotowania są trzy artykuły zajmujące się problematyką emigracji, zarówno w aspekcie teoretycznym, jak i historycznoliterackim. Wypełniają one wiele luk istniejących ciągle w badaniach nad literaturą i życiem literackim poza krajem. Mamy, przede wszystkim dzięki wieloletnim dociekaniom Aliny Witkowskiej, sporą wiedzę o Wielkiej Emigracji romantycznej, trochę prac dotyczących powojennej literatury emigracyjnej oraz funkcjonowania ośrodków i skupisk polskiego życia kulturalnego na obczyźnie. Lektura artykułów Maciejewskiego uświadamia jednak, jak wiele w tej dziedzinie pozostało do zrobienia. Przynajmniej przez dwa wieki mamy przecież do czynienia z rozdwojeniem polskiej kultury, a przywołane tu artykuły znacznie ten obszar czasowy pozwalają rozszerzyć. Janusz Maciejewski nie poprzestaje tutaj na wskazaniu specyfiki twórczości powstającej 
w oderwaniu od jej naturalnego, geograficznego, społecznego i narodowego podłoża. Przede wszystkim analizuje różnorodność zjawisk często określanych wspólnym, skrajnie uproszczonym mianem emigracji, takich jak wygnanie, wyobcowanie, wychodźstwo, przesiedlenie itp. Dalej — przypomina w porządku historycznoliterackim kolejne fale emigracyjne, bada ich związki z krajem, zakres oddziaływania, uczestniczenia i wpływania na literaturę krajową. Wystrzegając się jednoznacznych ocen, wskazuje nie tylko na straty - zubożenic narodowych zasobów kultury, gdy opuszczały kraj wybitne, twórcze jednostki czy grupy. Macicjewski dostrzega także pozytywne oddziaływanie emigracji, otwarcie się Polski na światowe prądy i nurty z jednej, a propagowanie kultury polskiej w krajach osiedlenia się emigrantów z drugiej strony.

Ostatnia, piąta część książki Maciejewskiego ma nieco inny charakter. Artykuł Rozwoój wiedzy o literaturze polskiej po 1918 roku stanowi zwięzly i przejrzysty przegląd metod i osiągnięć dwudziestowiecznego literaturoznawstwa polskiego. Zamykające tom studium Ksztattowanie się syntezy dziejów literatury polskiej w powojennych dziesięcioleciach nie tylko pokazuje najwybitnicjsze osiągnięcia w zakresie historii literatury powstałe po wojnie. Jego wielkiej zalety dopatruję się w dokonanej tu rekonstrukcji nowego typu badacza, ujawnieniu nie tylko nowych możliwości badawczych, jakie stąd wynikają, ale także zagrożeń. Dążenie do mnożenia wewnętrznych podziałów w obrębie nauki o literaturze i powstawanie coraz węższych specjalizacji nie sprzyja tworzeniu syntez literackich, a wręcz je uniemożliwia. Skończyła się epoka Kleinerów, Chrzanowskich, Krzyżanowskich, tych, którzy dostrzegali, że kultura jest całością. Cenne, często nowatorskie i odkrywcze prace cząstkowe, specjalistyczne, odnoszące się do jednego pisarza, jednej epoki czy jednego problemu, gdzieś tę całość gubią, nie mówiąc już o braku jednolitej metodologii, którą należałoby w jej tworzeniu zastosować. Albo też, co chyba jest jeszcze gorsze, prezentują spojrzenie na całość z perspektywy drobnych wycinków, fragmentów, absolutyzując je i wypaczając obraz, niwelując różnice, przykrawając materiał literacki do własnych potrzeb, mnożąc sztuczne podziały. Stąd punktem dojścia rozważań Maciejewskiego staje się postulat powrotu do syntezy. Autor tworzy także modelowy projekt idealnego podręcznika, prezentującego całość polskiej literatury w jej związkach z życiem społecznym, instytucjami kultury i specyfiką okresów historycznych, czyli tym wszystkim, co nazywa „informacją okołotekstową".

Podsumowując te, z konieczności dość pobieżne, uwagi, należy stwierdzić, iż książka Janusza Maciejewskiego jest ważną i godną zainteresowania pozycją w polskim literaturoznawstwie. Przywoluje bardzo wiele istotnych dla niego problemów i kwestii. Zwraca uwagę na te „obszary i konteksty” literatury, które ciągle jeszcze nie znalazły należytego im miejsca w pracach naukowych. Podkreślić należałoby także inspirującą rolę, jaką książka Maciejewskiego może odegrać. Każdy z zawartych w niej artykułów prowokuje do dalszych docickań, do szerszego i głębszego podjęcia omawianych tu kwestii z wykorzystaniem narzędzi badawczych proponowanych przez autora. I wreszcie, co nie jest bez znaczenia, praca napisana jest przejrzystym, wolnym od naukowej napuszoności językiem, może być przystępna nie tylko 
dla wąskiego grona specjalistów, ale także dla innych grup czytelników interesujących się mechanizmami funkcjonowania życia literackiego i różnymi obszarami literatury. Na pewno bardzo przydatna byłaby także w nauczaniu akademickim.

Danuta Dąbrowska

\section{Sarajewo opłakane}

Nie tylko literatura polska z okresu II wojny światowej zadała kłam powszechnie znanemu powiedzeniu Inter arma... Także w czasach współczesnych spotykamy się z podobnym zjawiskiem. Rozgrywająca się niejako na naszych oczach tragedia wojny na Bałkanach również odcisnęła swoje piętno na literaturze. Polski czytelnik mógł się o tym przekonać dzięki inicjatywie wydawniczej Fundacji „Pogranicze”, która patronowała „Bibliotece Pisarzy Sarajewa”. W serii tej ukazało się sześć tomików poetyckich i dwa prozatorskie ${ }^{1}$. Ich autorzy są przedstawicielami różnych generacji pisarskich i różnych narodowości (zresztą sprawa przynależności narodowościowej w porozdzieranej wojną byłej Jugosławii jest niezwykle skomplikowana), ale łączy ich jedno — traumatyczne doświadczenie obecności w oblężonym Sarajewie. To właśnie Miasto staje się głównym bohaterem tworzonych przez nich wierszy i opowiadań. Podkreśla to tytuł opublikowanej również przy współudziale Fundacji „Pogranicze" antologii Lament nad Sarajewem ${ }^{2}$, w której znalazły się, w rozszerzonej wersji i w nowym przekładzie, utwory poetów obecnych w „Bibliotece Pisarzy Sarajewa”.

W twórczości sarajewskich poetów dominuje poczucie osaczenia, zamknięcia w sytuacji pozbawionej wyjścia. Miasto, w którym przyszło im żyć, „zamordowane i wygłodniałe" (Tontić Konfitury), „upiorne” (Simić Lament nad ratuszem), stało się „teatrem śmierci”, „wielkim więzieniem” (Simić Doniesienie prasowe o paczkach), "pułapką na ludzi” (Skrinjar-Tvrz Ogtoszenie). Wiersze, które powstają w tych warunkach, mają charakter dokumentalny — są to reportaże z więzienia. Przedstawiają codzienne życie mieszkańców oblężonego miasta: zdobywanie żywności i wody, ukrywanie w piwnicach, ucieczki przed kulami snajperów, oswojenie z widokiem ran i śmierci, pogrzeby „w parkach miejskich i przydomowych ogródkach" (Osti Uktadano sobie życie z umartymi); opisują wojenny pejzaż: wypalone domy, mieszkania „bez drzwi i okien” (Osti $W$ tym mieście...), powycinane na opał parki; upamięt-

\footnotetext{
${ }^{1}$ F. Duraković, Przeprowadzka z pięknego kraju w którym umierają róże, przekł. M. Szmyt; I. Kordić, Szukaliśmy domu, przekł. A. Bloch; J. Osti, Wszystkie flagi sq czarne, przeł. i wybrał J. Kornhauser; I. Sarajlić, Sarajenski tomik wojenny, przekł. D. Cirlić-Straszyńska, M. Grześczak; G. Simić, Płacz Sarajew’a, przekł. B. Nowak; V. Skrinjar-Tvrz, Sarajewskie grafiki, przekł. M. Kordowicz; S. Tontić, Glupie twoje serce, zajqczku, przekł. D. Cirlić-Straszyńska; M. Trumić, Mojemu listonoszowi z wyrazami mitości, przekł. A. Bloch, M. Szmyt, S. Babić-Barańska, Fundacja „Pogranicze”, Sejny 1995.

${ }^{2}$ Lament nad Sarajewem. Siedmiu poetów z Bośni, wyb., przekł. i sł. wst. J. Kornhauser, Wydawnictwo „13 Muz”, Szczecin i Fundacja „Pogranicze”, Sejny 1996.
} 